\title{
The Independent Campus, Freedom to Learn (Mbkm) Policy Socialization Model as an Effort to Achieve the Main Performance Indicators of Higher Education
}

\author{
Tanti Kirana Utami ${ }^{1}$, Dedi Mulyadi ${ }^{2}$, M. Rendi Aridhayandi ${ }^{3}$, Henny Nuraeny ${ }^{4}$, Cecep Wirahma $^{5}$, Siti \\ Maryam $^{6}$, Sri Mulyanti ${ }^{7}$ \\ 1,2,3,4,5 Faculty of Law, Universitas Suryakancana. \\ ${ }^{6,7}$ Faculty of Teacher Training and Education, Universitas Suryakancana.
}

\begin{abstract}
Independent campus learning provides challenges and opportunities to develop innovation, creativity, capacity, personality, and student needs. Through an independent learning program that is well designed and implemented, students' hard and soft skills can be improved. The implementation of MBKM at Universitas Suryakancana is based on several main principles: referring to the Achievement of Graduate Profiles, Referring to the Demands of 21st Century Capabilities, Increasing Collaborative Competencies, Increasing Independent Learning, Adapting to Demands and Needs. The research method uses a normative juridical approach with analytical descriptive specifications. The results showed that the MBKM policy socialization process could be carried out in stages and continuously with the assistance of persons or people who represent the academic community in carrying out socialization activities.
\end{abstract}

Keywords: Main Performance Indicators, MBKM, Socialization.

\section{Introductions}

The learning process in an independent campus is one of the essential manifestations of student-centered learning. Independent on-campus learning provides challenges and opportunities for the development of innovation, creativity, capacity, personality, and student needs, as well as developing independence in seeking and finding knowledge through realities and field dynamics such as ability requirements, real problems, social interaction, collaboration, self-management, performance demands, targets, and achievements. Through an independent learning program that is well designed and implemented, students' hard and soft skills will be formed strongly. The MBKM program is expected to answer the challenges of higher education to produce graduates who are following the times, advances in science and technology, the demands of the business and industrial world, and the dynamics of society. The MBKM guidelines are theoretically based on the main principles of the Central MBKM Policy as regulated in Permendikbud Number 3 of 2020 concerning National Standards for Higher Education, in Article 18.

The MBKM concept, as conveyed by the Director of Learning and Student Affairs of the Director-General of Higher Education, Aris Junaidi (2020), who explained that MBKM is a policy of the Minister of Education and Culture, which aims to encourage students to master various sciences that are useful for entering the world of work. Merdeka Campus provides an opportunity for students to choose the courses they will take. Learning in the Merdeka Campus offers challenges and opportunities to develop creativity, capacity, personality, and student needs. In addition, independent Campus learning aims to build independence in seeking and finding knowledge through realities and field dynamics such as ability requirements, real problems, social interaction, collaboration, self-management, performance demands, targets, and achievements. Based on the above, it is interesting to study how the implementation of MBKM 
policies at Universitas Suryakancana and the appropriate socialization model in increasing the understanding of lecturers, education staff, and students regarding MBKM policies.

\section{Method}

The method used in this research is normative juridical with data collection techniques using literature studies and field studies equipped with survey methods supported by relevant reference sources. This study examines the origins of primary data and secondary data.

\section{Results and Discussions}

MBKM is one of the Minister of Education and Culture policies, Nadiem Makariem. One of the MBKM policy programs is the Right to Learn Three Semesters Outside the Study Program. The program mandates various regulations/legal foundations of higher education to improve the quality of learning and higher education graduates. To prepare students to face changes in social, cultural, the world of work, and rapid technological advances, student competencies must be more responsive to the needs of the times. Link and match with the world of industry and the world of work and a rapidly changing future. Universities must design and implement innovative learning processes so that students can achieve learning outcomes covering aspects of attitudes, knowledge, and skills optimally and continuously relevant. The MBKM policy is expected to be the answer to these demands. The Merdeka Campus is a form of learning in higher education that is autonomous and flexible to create a learning culture that is innovative, unfettered, and following the needs of students (Kemdikbud, 2020).

The legal basis for the implementation of the Three Semester Learning Rights Policy program outside the Study Program includes the following:

a. Law Number 20 of 2003 concerning the National Education System;

b. Law Number 12 of 2012, concerning Higher Education;

c. Law Number 6 of 2014, concerning Villages;

d. Government Regulation Number 04 of 2014, concerning the Implementation of Higher Education and Management;

e. Presidential Regulation number 8 of 2012, concerning KKNI;

f. Regulation of the Minister of Education and Culture of the Republic of Indonesia Number 3 of 2020, concerning National Standards for Higher Education;

g. Regulation of the Minister of Villages, Development of Disadvantaged Regions, and Transmigration Number 11 of 2019, concerning Priorities for the Use of Village Funds in 2020;

h. Regulation of the Minister of Villages, Development of Disadvantaged Regions, and Transmigration Number 16 of 2019, concerning Village Deliberations;

i. Regulation of the Minister of Villages, Development of Disadvantaged Regions, and Transmigration Number 17 of 2019, concerning General Guidelines for Development and Empowerment of Village Communities;

j. Regulation of the Minister of Villages, Development of Disadvantaged Regions, and Transmigration Number 18 of 2019, concerning General Guidelines for Village Community Assistance (Kemdikbud, 2020).

The definition of socialization, according to Charles R Wright, quoted by Sutaryo (2004), is "the process by which individuals acquire the culture of their group and internalize to a certain degree their social norms, thus guiding that person; to take into account the expectations of others." Socialization, when associated with the process, there are types of socialization. According to Peter L Berger and Luckman, there are two types of socialization, namely: a) Primary socialization, the first socialization that individuals undergo as a child by learning to become members of society (family). This socialization takes place in childhood; b) 
Secondary socialization is an advanced process after primary socialization that introduces individuals to specific groups in society (Sudarsono, 2021).

According to the Big Indonesian Dictionary (2021), socialization is a) an effort to change the individual property into a public property (state-owned): tradition does not facilitate the process - family-owned company b) the learning process of a member of the community to recognize and appreciate the culture of the community in their environment: the initial stages of the process -- humans occur in the family environment; c) efforts to socialize something so that it becomes known, understood, and lived by the community; correctional.

According to Bruce J. Cohen, socialization is a social process where an individual gets the formation of attitudes to behave following behavior both as an individual and as a member of the people around him. The socialization process is a process of learning and instilling a value, norm, role, and pattern of behavior from one generation to another in terms of a group or society to participate in people's lives. The form or model of socialization can be classified into two, namely, the participatory socialization system model and the repressive socialization model. The participatory system model, this socialization model has consciously involved other people voluntarily. This model was developed by someone who wants some form of communication and relationship with other people without coercion. The essence of this socialization is the interest of two people who socialize with each other, and there is an element of awareness to communicate and socialize. This form of socialization is a freedom that cannot be forced by any party and by anyone. The second is the Repressive socialization model. This socialization goes in one direction from one person to another. This kind of relationship can be seen in a pattern or structural relationship within an organization (Niken Lestarini, 2017).

Socialization is a process where a person internalizes concepts, values, ideas, or ideas to other people in a group or social institution to create participation (participation) in the group or social institution (Arry Dharmawan Trissatya Putra, 2016). James W. Vander Zanden (Damsar, 2011) defines socialization as "a process of social interaction by which people acquire knowledge, attitudes, values, and behaviors essential for effective participation in society.

Socialization is defined as a lifelong process of how an individual learns habits that include ways of life, values, and social norms that exist in society to be accepted by the community. In general, socialization is defined as teaching or transferring habits or discounts and rules from one generation to another in a group or society. Socialization is also known as role theory. Because in the socialization process, individuals' roles must be carried out are taught (Arry Dharmawan Trissatya Putra, 2016).

Paul B Horton and Chester Hunt say that socialization is a process in which a person internalizes the norms of the group in which he lives so that a unique self emerges (Susilastuti Dwi N., Susilo, and Zudiyatko, 2011). Charles R. Wright said that socialization is the process by which individuals acquire a group culture and internalize (to a certain degree) its social norms, thus guiding the person to take into account the expectations of others. It is important to emphasize that socialization is never "total" and is ongoing, moving from childhood to old age-some norms, such as basic rules about reasonable and proper procedures according to society. In short, this socialization teaches humans continuously throughout life in the community. Socialization responsibility is usually placed in the hands of certain people or institutions, depending on the normative area involved. A large amount of socialization is done intentionally, but socialization also occurs unconsciously when individuals take cues about social norms without any special lessons about them (Fajar, 2009).

The socialization process will not run well without the help of persons or people who are aware or not, in this case, working "representing" the community in carrying out socialization activities. Persons or people 
are divided into two: a) Persons who have authority and power over individuals who are socialized. For example, father, mother, teacher, boss, leader, and so on; b) Persons who have an equal position with the individuals being socialized. For example, peers, playmates, classmates, and so on (Narwoko \& Bagong, 2017).

Decree of the Minister of Education and Culture Number 754/P/2020 as amended by Decree of the Minister of Education and Culture Number 3/M/2021. To realize the ideals of higher education, changes must be made in evaluating higher education performance which will be assessed based on the Main Performance Indicators (KPI). The Main Performance Indicators issued by the Minister of Education and Culture through the Decree of the Minister of Education and Culture Number 754/P/2020 are new performance measures for higher education institutions to realize adaptive higher education based on more concrete outputs. The policy is also a measuring tool to accelerate the implementation of MBKM (Kemendikbud, 2020).

Leading Performance indicators of universities that are determined must focus on the three development mandates. Every State Universities and Higher Education Service Institutions within the Ministry of Education and Culture must be guided by the leading performance indicators in a. set targets for Key Performance Indicators; b. compiling contract documents or performance agreements; c. implement Key Performance Indicators; d. monitor Key Performance indicators; e. evaluate Key Performance indicators; f. make improvements to the critical sustainable performance indicators; and g. report the results of the achievement of Key Performance indicators.

Apart from being based on the mandate of developing higher education, the Main Performance Indicators Higher Education must be able to be a measuring tool as well as an accelerator for the development of the Independent Learning policy: Independent Campus, which has been stipulated through the Regulation of the Minister of Education and Culture Numbers 3, 4, 5, 6, and 7 of 2020 Through this policy, the Ministry of Higher Education seeks to ensure higher education institutions have high adaptability to changing times, have a more direct impact on society and can achieve international higher education standards. Guarantees of convenience and sharper targets are also lecturers as the leading resources in higher education. A magnificent building will feel empty without being filled by qualified lecturers. Lecturers are encouraged to carry out problem-based, collaborative learning and not rely on learning in the classroom. As a final result, the independent Campus policy is expected to provide a favorable climate for developing student interests and talents. Students can hone their skills in innovative, flexible learning situations based on student curiosity and sound according to problems in society or industry needs. So that when students graduate, they can become human resources who are ready to learn for life, are adaptive, and have high competitiveness.

Key Performance Indicators in higher education consist of:

Key Performance Indicator1: Graduates Get Decent Jobs

Key Performance Indicator 2: Students Gain Off-Campus Experience

Key Performance Indicator 3: Lecturer Activities Outside Campus

Key Performance Indicator 4: On-Campus Teaching Practitioners

Key Performance Indicator 5: Lecturer's Work Is Used By The Community Or Gets International Recognition

Key Performance Indicator 6: Study Programs in Collaboration with World-Class Partners

Key Performance Indicator 7: Collaborative and Participatory Classroom

Key Performance Indicator 8: International Standard Study Program

Universitas Suryakancana is one of the universities that carry out the duties and functions to educate the nation's life. Universitas Suryakancana aims to prepare humans to become members of society who have academic or professional abilities who can apply, develop and enrich science, technology, and art and improve the dignity of the community as human resources who are faithful devoted. Universitas Suryakancana, as a scientific community in implementing the Tridharma of Higher Education, is determined 
Tanti Kirana Utami et./al The Independent Campus, Freedom to Learn (Mbkm) Policy Socialization Model as an Effort to Achieve the Main Performance Indicators of Higher Education

to keep trying to maintain and improve its ability to explore, develop, and practice science, technology, and art with national insight global orientation based on local wisdom. Through the Decree of the Minister of Education of the Republic of Indonesia Number 100/D/0/2001, dated August 2, 2001, UNSUR officially has 5 (five) faculties with 13 (thirteen) undergraduate programs and 2 (two) master's programs (Universitas Suryakancana, 2020). The implementation of MBKM at Universitas Suryakancana is based on several main principles: referring to the Achievement of Graduate Profiles, Referring to the Demands of 21st Century Capabilities, Increasing Collaborative Competencies, Increasing Independent Learning, Adapting to Demands and Needs.

The implementation of the MBKM policy at Universitas Suryakancana is exciting to study, so the author conducted this research starting with surveying the Indonesian Online Learning System (SPADA) link in December 2021 with a total sampling method of 2,328 (two thousand three hundred twenty-eight) students, 80 (eighty) lecturers and 39 (thirty-nine) education staff.

In general, lecturers at Universitas Suryakancana who know the overall policy as much as $16 \%$ already know most of the contents of the MBKM curriculum policy as much as $60 \%$. While $21 \%$ only know a little, the lecturers who do not know at all are 3\%. Efforts can be taken to carry out massive socialization through various academic and non-academic activities, for example, at lecturer meetings, scientific meetings, and so on. Furthermore, the education staff at Universitas Suryakancana, in their knowledge of MBKM policies, have not been optimal in looking at the survey results; namely, only $8 \%$ who know the policy as a whole know most of the contents of MBKM policies as much as $49 \%$, who know a little as much as $43 \%$. Based on the preceding, MBKM socialization must be provided in stages and continuously. Students' level of understanding regarding MBKM policies is generally good, and this is evidenced by only $13 \%$ who do not know anything about MBKM policies. This shows that the study program plays a significant role in the socialization of MBKM policies for students.

Information media used by the Universitas Suryakancana community related to MBKM policies can be seen from the survey results below:

\section{Lecturer}

\section{INFORMASI MENGENAI KEBIJAKAN MERDEKA BELAJAR-KAMPUS MERDEKA (MBKM)}



Figure 1. Results of the MBKM Policy Survey through SPADA December 2021 
Tanti Kirana Utami et./al The Independent Campus, Freedom to Learn (Mbkm) Policy Socialization Model as an Effort to Achieve the Main Performance Indicators of Higher Education

Based on Figure 1, sources of information on MBKM policies for lecturers come from 1) offline/online social activities organized by universities by 37 percent; 2) Ministry of Education and Culture's online channels (Website and Social Media) by 29 percent; 3) Offline/online social activities organized by the Ministry of Education and Culture are 19 percent; 4) Higher Education online channels (Websites and Social Media) by 6 percent; 5) Mass media 4 percent; 6) another 3 percent; and 7) Community communication channels by 1 percent..

\section{Education Personnel}

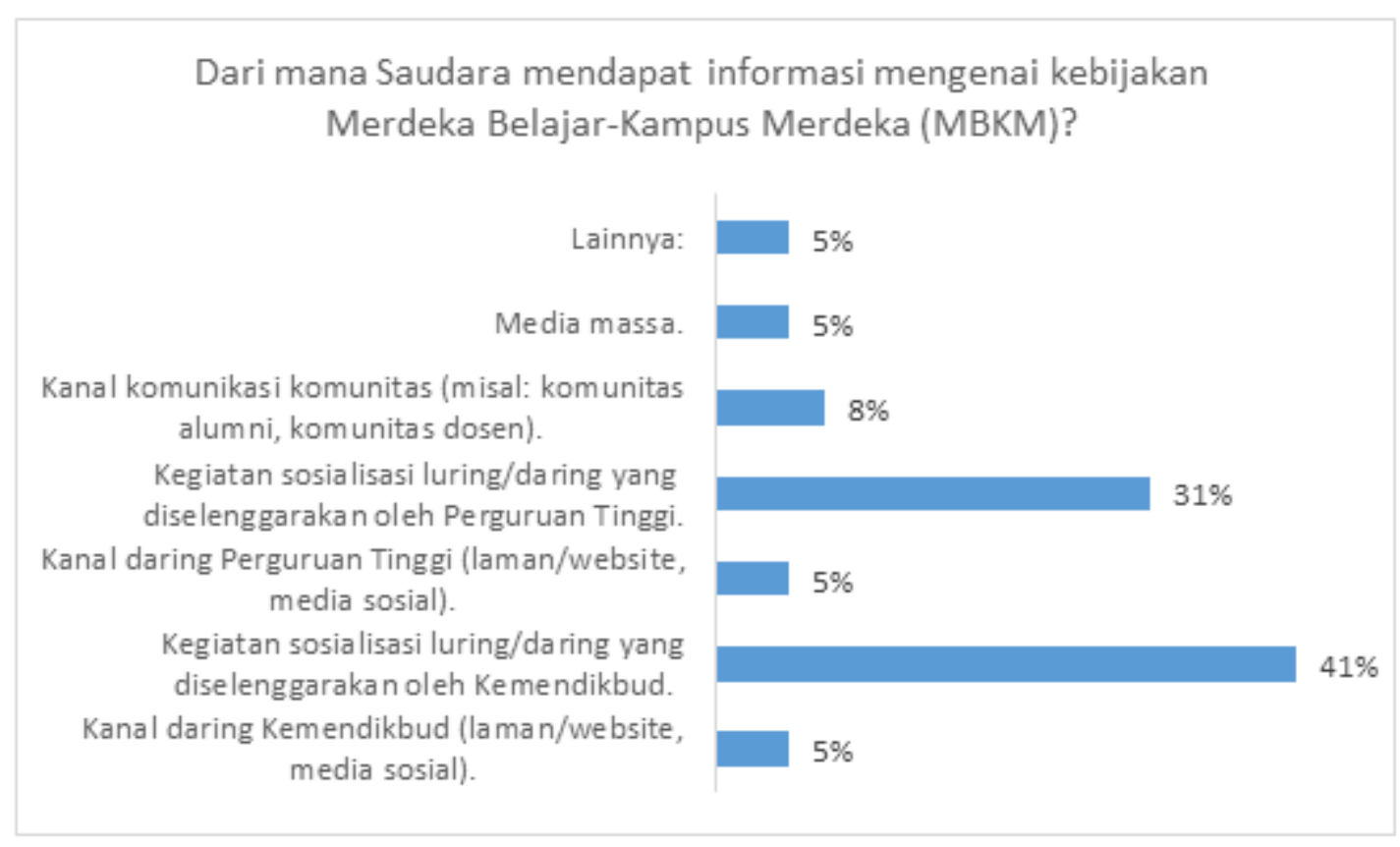

Figure 1. Results of the MBKM Policy Survey through SPADA December 2021

Based on Figure 2, the sources of information on MBKM policies for education staff are from 1) offline/online social activities organized by universities by 41 percent; 2) Offline/online social activities organized by the Ministry of Education and Culture are 31 percent; 3) Community communication channels by 8 percent; 4) Ministry of Education and Culture's online channels (Website and Social Media) by 5 percent; 5) Higher Education online channels (Websites and Social Media) by 5 percent; 6) Mass media by 5 percent; 6) another 5 percent; and 7) Ministry of Education and Culture's online channels by 5 percent.

\section{Student}


Tanti Kirana Utami et./al The Independent Campus, Freedom to Learn (Mbkm) Policy Socialization Model as an Effort to Achieve the Main Performance Indicators of Higher Education

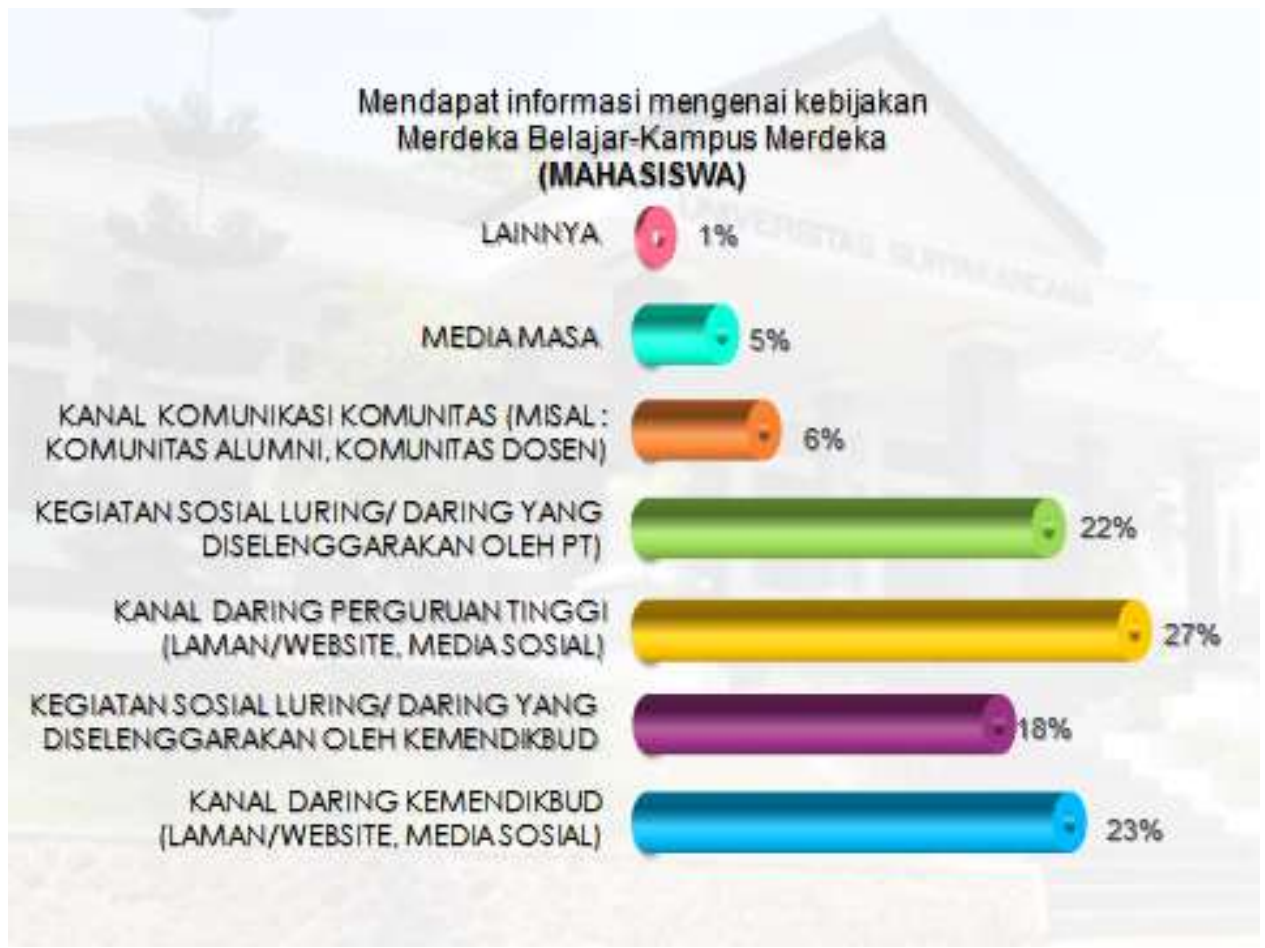

Figure 1. Results of the MBKM Policy Survey through SPADA December 2021

Based on Figure 3, the sources of information on MBKM policies for students come from 1) College online channels (Websites and Social Media) by 27 percent; 2) Ministry of Education and Culture's online channels by 23 percent; 3) Offline/online social activities organized by PT by 22 percent; 4) Offline/online social activities organized by the Ministry of Education and Culture are 18 percent; 5) Community communication channels by 6 percent; 6) Mass media by 5 percent; 7) another 1 percent.

Based on the survey results above, the lecturers and education staff who became respondents received the most information about MBKM policies through offline/online socialization activities organized by universities. This shows that the importance of socialization carried out by universities.

Constraints faced in implementing the MBKM program include funding, human resources, curriculum adjustments, and MBKM information system adjustments. Efforts made: a) Formed a Person In Charge (PIC) at the University Level, with the tasks at the time being; b) Develop a policy of socialization in stages; c) Socialization is carried out to lecturers, staff, and students; d) The socialization system is carried out in stages starting from the University Level, Faculty Level, and Study Program Level; e) PIC University conducts socialization at the University Level with the participants of Lecturers, Educators, and Students as Trainers who will carry out outreach at the Faculty Level; f) Faculties carry out socialization conducted by Lecturers, Educators, and Students who have received socialization at the University Level (Trainers) to all Study Programs;

\section{Conclusion}

The process of socializing the MBKM policy can be carried out in stages and continuously with the assistance of persons who are aware or not, in this case working to "represent" the academic community in carrying out socialization activities that have authority and power over individuals who are the target of socialization. For example, leaders, lecturers who are experienced in the MBKM field can also be carried out by persons who have an equal position with the individuals being socialized, such as lecturers and education staff. The implementation of the MBKM curriculum must be contained in various MBKM regulations. University Budgets, Faculty Budgets so that the socialization activities carried out in stages can be carried out with sufficient funding. A Person In Charge (PIC) is formed at the Faculty Level as part of the duties of the Deputy Dean for Academic Affairs. 


\section{Acknowladgements}

The authors would like to thank the Secretariat of the Directorate General of Higher Education, Research and Technology of the Directorate General of Higher Education, Research and Technology of the Ministry of Education and Culture of Research and Technology of the Republic of Indonesia, which has provided funds for the implementation of this research through the Funding Assistance Program for the Independent Learning Policy Research Program. Independent Campus and Community Service Based on Research Results and Prototypes of Private Universities in 2021.

\section{References}

1. Arry Dharmawan Trissatya Putra, Inovasi Model Sosialisasi Peran Serta Masyarakat Dalam Pemilu, Jurnal Wacana Politik, vol. 1, No. 2, Oktober 2016.

2. Damsar. 2011. Pengantar Sosiologi Politik. Lampung: Kencana Prenada.

3. Fajar, Maharani, 2009, Ilmu Komunikasi Teori dan Praktek, Graha ilmu, Yogyakarta.

4. https://kbbi.web.id/sosialisasi, diakses tanggal 15 desember 2021.

5. Kemendikbud RI, Buku Pedoman IKU PTN.

6. Kemendikbud, Buku panduan MBKM, 2020.

7. Narwoko \& Bagong, Sosiologi Teks Pengantar dan Terapan (Jakarta: Kencana, 2007).

8. Niken Lestarini, Pengembangan Model Sosialisasi Jaminan Kesehatan Nasional, Melalui Peran Opinion Leader /08/Vol. 05/No. 02 Juni 2017.

9. Sudarsono, Pengantar Sosialisasi, (wikipediaindonesia.melaluihttp://id.wikipedia.org wiki/sosialisasi di akses 12 Desember 2021.

10. Susilastuti Dwi N., Susilo, dan Zudiyatko, Model Komunikasi dalam Sosialisasi Undang-Undang No 23 Tahun 2004 tentang Penghapusan Kekerasan dalam Rumah Tangga, Jurnal Ilmu Komunikasi, Volume 9, Nomor 1, Januari - April 2011.

11. Sutaryo, Dasar-Dasar Sosialisasi, (Jakarta: Rajawali Press, 2004).

12. Universitas Suryakancana, Buku pedoman MBKM, 2020. 